\title{
A New Species of Crangonid Shrimp of the Genus Philocheras (Crustacea: Decapoda: Caridea) from Hawai ${ }^{\prime}{ }^{1}$
}

\author{
Tomoyuki Komai ${ }^{2}$
}

\begin{abstract}
Pbilocheras breviflagella, a new species of crangonid shrimp, is described and illustrated on the basis of a single ovigerous female collected from $\mathrm{O}^{\prime}$ ahu, Hawai' $\mathrm{i}$, at subtidal depth. The new species is most similar to P. sabsechota (Kemp, 1911) known with certainty only from the Andaman Islands, eastern Indian Ocean. It differs from $P$. sabsechota in several features, including the much narrower rostrum, the unarmed second lateral carina of the carapace, and the truncate posterior margin of the uropodal exopod. Other differences include the shorter fingers (each with an elongate unguis) of the second pereopod, and medially notched posterodorsal margins of the second and fourth abdominal somites. The new species is the first representative of the genus found to occur in the central Pacific.
\end{abstract}

The genus Philocheras Stebbing, 1900, is the most speciose among the Crangonidae, including nearly 50 species worldwide (de Man 1920, Holthuis 1951, 1961, Yaldwyn 1960, 1971, Zarenkov 1968, Crosnier 1971, Fujino and Miyake 1971, Dardeau 1980, Chace 1984, Wicksten 1989, Burukovsky 1990a,b, Bruce 1994, De Grave 2000, Kim and Hayashi 2000). Although Kemp (1911) synonymized Philocheras with Pontophilus Leach, 1817 , the genus was revived on the basis of the laterally unarmed rostrum, the absence of a postorbital suture on the carapace, and the absence of an exopod on the first pereopod (Chace 1984). Christoffersen (1988) showed that Philocheras is a clade, characterized by one autapomorphy (the antennular stylocerite is transversely oblong) and one homoplasy (the exopod is absent from the first pereopod). Philocheras is well represented in the Indo-West Pacific by 19 species, but there has been no record of the genus from the central Pacific, including Hawai'i.

${ }^{1}$ Manuscript accepted 7 February 2001.

2 Natural History Museum and Institute, Chiba, 955-2 Aoba-cho, Chuo-ku, Chiba 260-8682, Japan (E-mail: komai@chiba-muse.or.jp).

Pacific Science (2001), vol. 55, no. 4:419-427 (C) 2001 by University of Hawai'i Press All rights reserved
During an ongoing study of Crangonidae in the Indo-Pacific, a small ovigerous specimen from $\mathrm{O}^{\prime}$ ahu, Hawai'i, was made available for study by Dr. P. K. L. Ng of the National University of Singapore. Detailed examination has shown that this specimen represents a distinct undescribed species of Philocheras. Although only a single specimen was available for examination, its distinctiveness has led me to describe it as a new species, $P$. breviflagella. This new species represents the first record of Philocheras in the central Pacific.

The holotype is deposited in the Raffles Museum of Biodiversity Research, National University of Singapore (zRC). The abbreviation "cl" indicates postorbital carapace length. The drawings were made with the aid of a drawing tube mounted on a stereomicroscope (Leica MZ8).

\section{TAXONOMIC ACCOUNT}

Philocheras breviflagella Komai, n. sp. Figures 1-3

MATERIAL EXAMINED: Holotype: Ala Moana, O'ahu, Hawai'i, subtidal, 22 December 1999, coll. D. Takaoka, ovigerous female (cl $2.6 \mathrm{~mm}$ ) (zRC 2000.0369).

DESCRIPTION: Body (Figure $1 A, B$ ) robust, slightly flattened dorsoventrally. Integument of carapace and abdomen microscopically pitted, with scattered short (curled) or long (plumose) setae. 
Rostrum (Figure $1 A, B$ ) reaching anterior margin of corneas of eyes, broad, constricted at midlength; anterior margin weakly concave, its width 0.16 of carapace length; dorsal surface deeply concave; lateral margins greatly elevated, unarmed, forming supraorbital eave covering base of ocular peduncle; anterolateral angle rounded; ventral margin weakly concave in lateral view. Carapace (Figure $1 A, B$ ) almost as long as wide, slightly broadened posteriorly; median carina extending from anterior 0.4 of carapace, becoming gradually obsolete in posterior 0.2 , terminating anteriorly in moderately large gastric spine, dorsal margin weakly sinuous in lateral view; first (dorsolateral) carina extending from anterior 0.2 to near posterolateral margin of carapace, somewhat convergent posteriorly against midline, divided in two sections by wide, shallow notch at about midlength of carina, anterior section distinct, posterior section becoming blunt posteriorly; hepatic carina beginning from anterior 0.14 of cara- pace, short, rather thick, anteriorly with mesially curved hepatic spine; branchiostegal carina sharp, supporting branchiostegal spine, extending to level of hepatic spine, unarmed; orbital margin strongly elevated; gastric region shallowly depressed on either side of midline; antennal spine showing as broad triangular projection with blunt apex; branchiostegal spine moderately large, reaching anterior margin of cornea of eyes, directed slightly dorsally and mesially; pterygostomian spine small, arising from ventromesial to base of branchiostegal spine.

Thoracic sternum broad, elevated medially, with long median spine reaching coxae of second pereopods.

Abdomen (Figure 1A,B) widest at second somite, abruptly becoming narrower at fourth somite. First somite with distinct transverse carina along posterodorsal margin on tergum, but without median carina; lateral longitudinal carina low, not in contact with transverse carina; pleuron rounded ventrally. Second so-
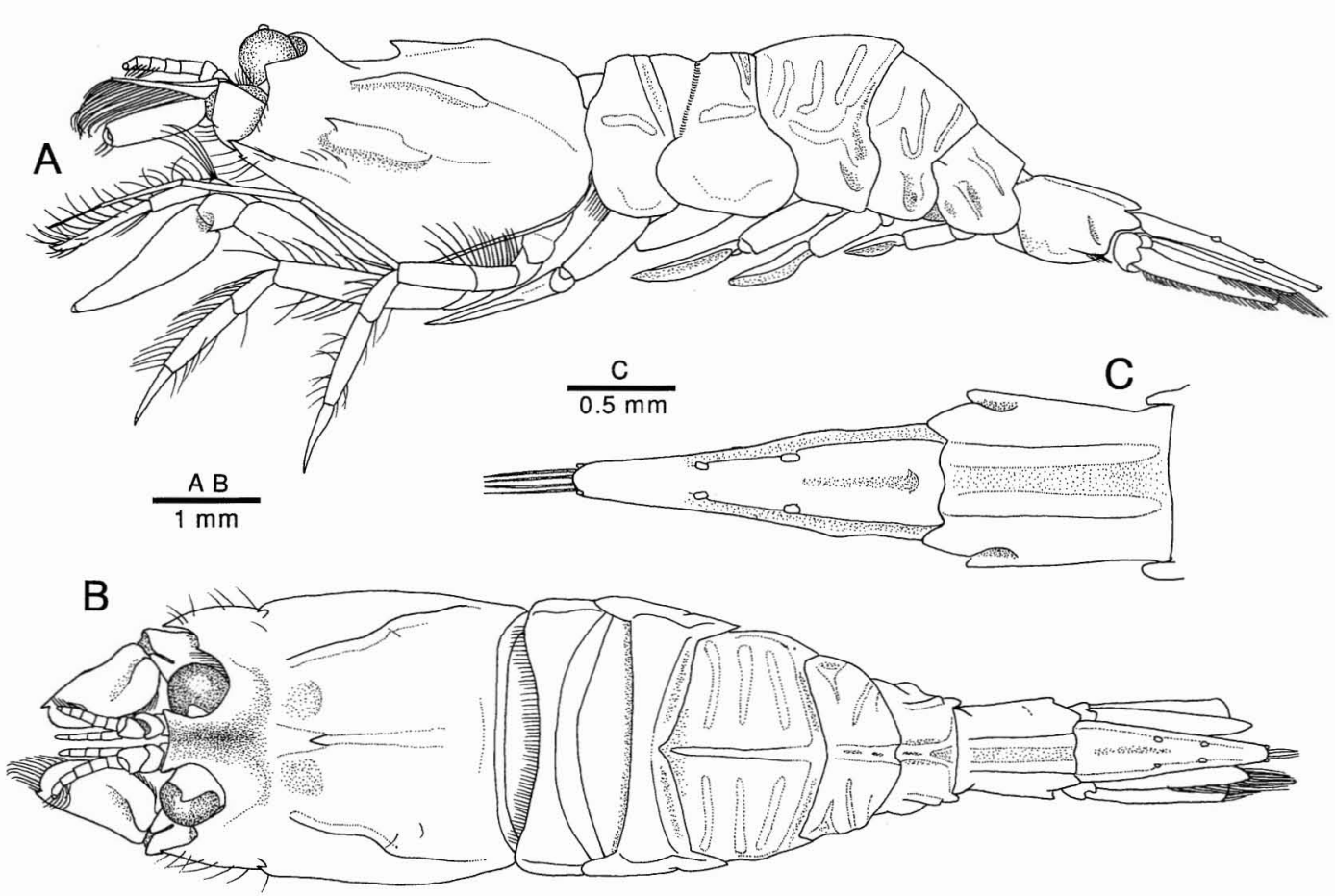

FIgURe 1. Philocheras breviflagella, n. sp. Holotype, ovigerous female from O‘ahu, Hawai'i (cl 2.6 mm; zRc 2000.0369). $A$, Entire animal, lateral; $B$, same, dorsal; $C$, sixth abdominal somite and telson, dorsal, setae partially omitted. 
mite with two transverse carinae on tergum; posterodorsal margin with deep median notch; lateral carina broad, faint, in contact with anterior transverse carina; pleuron with obtuse point on ventral margin. Third somite with distinct median carina running over entire length; tergum with four low transverse carinae, anterior three carinae not in contact with either median or lateral carina, posteriormost carina marginal, in contact with both median and lateral carinae; lateral carinae low, faint; pleuron with blunt angle on ventral margin. Fourth somite with low median carina bearing faint pits or depressions; posterodorsal margin with shallow, but distinct median notch; tergum and pleuron faintly sculptured by transverse carinae; ventral margin of pleuron forming blunt angle posteriorly. Fifth somite with low median carina, bifurcate posteriorly, anterior part with shallow median sulcus; tergum with obliquely transverse carina laterally; pleuron with short obliquely transverse (vertical) carinae laterally, ventral margin broadly rounded. Sixth somite (Figure $1 A-C$ ) with two low submedian carinae, each produced beyond posterodorsal margin as rounded lobe; lateral surface with row of scalelike setae along submedian carinae in posterior half; posterolateral process rounded; posteroventral angle forming subacute tooth; ventral surface shallowly concave, lacking preanal spine. Telson (Figure $1 C$ ) with broad median sulcus; dorsolateral ridges distinct in anterior 0.7 length of telson, with two pairs of small, distally truncate spines (anterior pair arising from 0.4 length of telson); posterior margin rounded, with one pair of tiny, blunt posterolateral spines and two pairs of long plumose setae.

Abdominal sternum unarmed medially.

Eye (Figure $1 A, B$ ) partially covered by orbit formed by rostrum and antennal spine of carapace; ocular peduncle short, slightly wider than cornea, with small, low tubercle dorsally and blunt protuberance on ventral face; cornea semispherical, lightly pigmented.

Antennular peduncle (Figures 1 $A, B, 2 A$ ) short, not reaching midlength of scaphocerite. Basal segment with deep fossa on dorsal surface proximally; stylocerite laterally oblong, lateral margin with blunt point. Penul- timate segment shorter than broad, with anterodorsal margin slightly produced. Ultimate segment short, unarmed. Dorsal flagellum very short and stout, falling slightly short of distal margin of antennal scaphocerite, composed of six articles (distal three articles with aesthetascs); ventral flagellum shorter than dorsal flagellum, composed of four articles.

Antenna (Figures $1 A, B, 2 B$ ) with basicerite stout, unarmed laterally. Scaphocerite 0.43 times as long as carapace and 1.96 longer than broad; lateral margin slightly sinuous, unarmed; distolateral tooth weakly curved mesially, reaching broadly rounded distal margin of blade; mesial margin strongly convex. Carpocerite weakly flattened dorsoventrally, slightly overreaching distal margin of scaphocerite. Flagellum broken off.

Mouthparts as usual in crangonids. Mandible (Figure $2 C$ ) with five distal teeth in total (three on external edge). Maxillule (Figure $2 D$ ) with proximal endite flattened, subovate, with row of sparse long setae on mesial margin; distal endite with four spines on truncate mesial margin. Maxilla (Figure 2E) with rudimentary endite bearing one long apical bristle; endopod curved mesially, tapering distally, with long plumose setae; posterior lobe of scaphognathite not elongate, but with very long setae on posterior margin. First maxilliped (Figure $2 F$ ) lacking endites; endopod flattened, with sparse row of long plumose setae on mesial margin; exopod with moderately narrow caridean lobe bearing row of setae on lateral margin; exopodal flagellum well developed; epipod well developed, bilobed (broken during dissection). Second maxilliped (Figure 2G) with three long spines on mesial margin of dactylus; exopod tapering distally, with well-developed flagellum; epipod small, devoid of podobranch. Third maxilliped (Figure $3 A, B$ ) overreaching distal margin of scaphocerite by half length of ultimate segment; antepenultimate segment flattened dorsoventrally in proximal half, somewhat inflated dorsally in distal half, with strongly sinuous mesial margin, unarmed distoventrally; distal two segments flattened dorsoventrally, with numerous transverse tracts of stiff setae and some long spini- 




Figure 2. Philocheras breviflagella, n. sp. Holotype, ovigerous female from O'ahu, Hawai'i (cl 2.6 mm; zRc 2000.0369). Left appendages. $A$, Antennular flagella, dorsal; $B$, antennal scaphocerite, dorsal, setae omitted; $C$, mandible, external; $D$, maxillule, external; $E$, maxilla, external; $F$, first maxilliped, external, epipod broken during dissection; $G$, second maxilliped, external; $H$, first pleopod, dorsal, setae partially omitted; $I$, second pleopod, dorsal, setae partially omitted. 


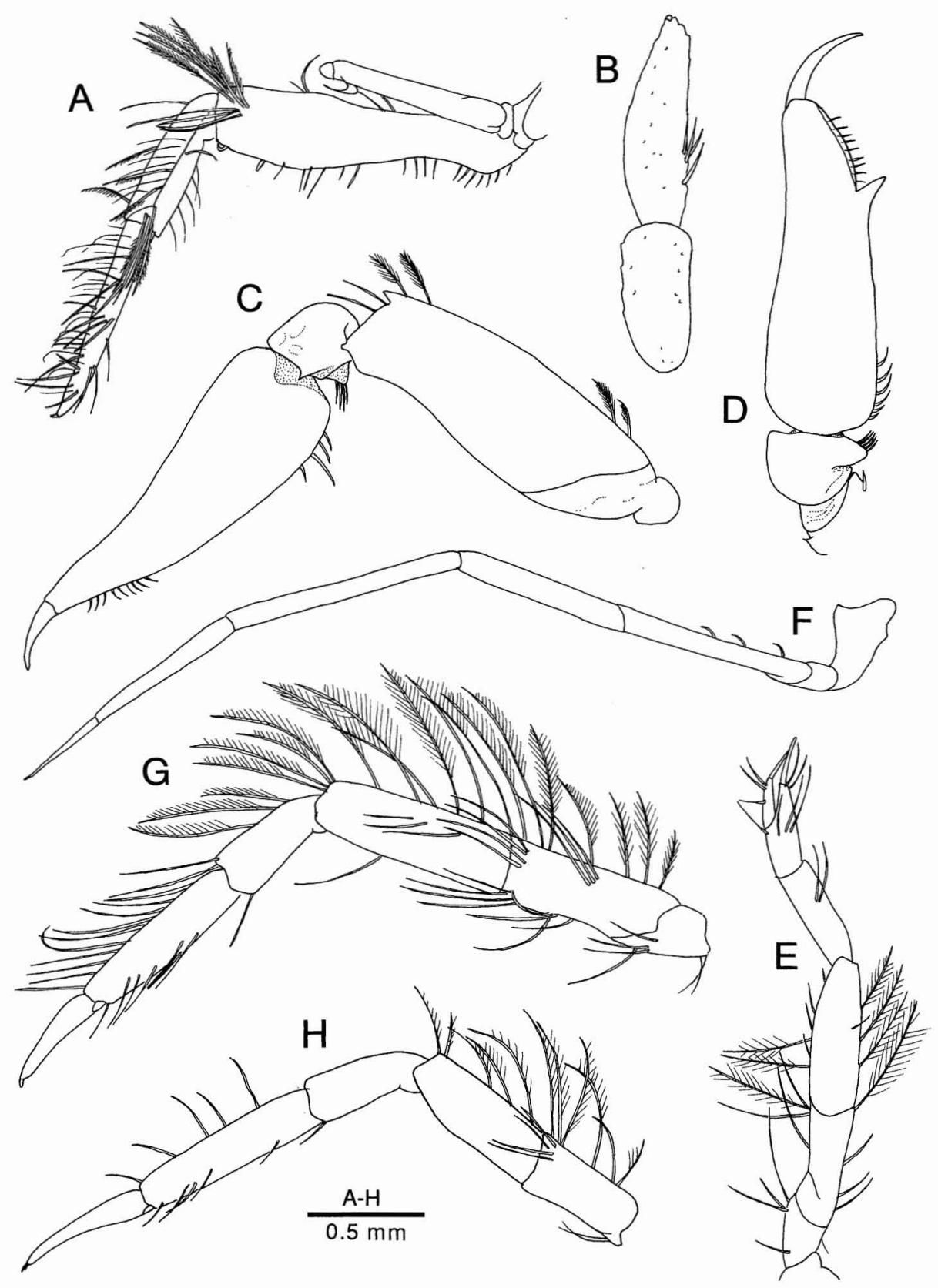

FIgURe 3. Philocheras breviflagella, n. sp. Holotype, ovigerous female from O'ahu, Hawai'i (cl 2.6 mm; zRc 2000.0369). Left thoracic appendages. $A$, Third maxilliped, lateral; $B$, same, distal two segments, dorsal, setae omitted; $C$, first pereopod, lateral; $D$, same, chela, dorsal; $E$, second pereopod, lateral; $F$, third pereopod, lateral; $G$, fourth pereopod, lateral; $H$, fifth pereopod, lateral. 
form setae on mesial face; ultimate segment longer than penultimate segment, gradually tapering distally, terminating in minute spinule; exopod reaching 0.6 length of antepenultimate segment, with well-developed flagellum.

First pereopod (Figure $3 C, D$ ) overreaching distal margin of scaphocerite by 0.25 length of palm. Merus strongly compressed laterally, with small dorsodistal spine; dorsal margin slightly convex; ventral margin sinuous, unarmed. Carpus short; lateral margin with small spine ventrally; ventromesial distal margin somewhat produced, with cluster of stiff grooming setae. Palm cylindrical in proximal 0.3, becoming flatter and narrower distally; lateral and mesial outline slightly sinuous in dorsal view; cutting edge strongly oblique, bordered by thin plate bearing row of marginal setae and of submarginal setae ventrally; fixed finger moderately stout. Dactylus weakly curved, not overreaching base of fixed finger when closed. Exopod absent.

Second pereopod (Figure 3E) much shorter than first pereopod, overreaching anterolateral margin of carapace by length of fingers. Coxa partially fused with sternum. Basis without dorsal process. Ischium slightly shorter than merus. Merus narrowed distally, with sparse plumose setae on dorsal and ventral margins. Carpus shorter than merus. Chela 0.9 times as long as carpus (excepting distal unguis of fingers), with sparse long setae; fixed finger shorter than dactylus, with elongate distal unguis longer than fixed finger. Dactylus equal in length to palm, with long unguis as long as dactylus.

Third pereopod (Figure $3 F$ ) slender, overreaching scaphocerite by length of dactylus and propodus. Ischium longer than merus. Carpus 1.4 times longer than merus. Propodus 0.7 times as long as carpus, tapering distally. Dactylus 0.54 times as long as carpus; distal unguis extremely slender, needlelike, 0.6 times as long as dactylus.

Fourth pereopod (Figure $3 G$ ) reaching scaphocerite by tip of dactylus. Ischium and merus with long plumose setae on dorsal and shorter simple setae on ventral surfaces, merus slightly longer than ischium. Carpus 0.63 times as long as merus, with few long simple
TABLE 1

Pbilocheras breviflagella, n. sp. Gill Formula

\begin{tabular}{|c|c|c|c|c|c|c|c|c|}
\hline & \multicolumn{3}{|c|}{ Maxillipeds } & \multicolumn{5}{|c|}{ Pereopods } \\
\hline & 1 & 2 & 3 & 1 & 2 & 3 & 4 & 5 \\
\hline Pleurobranchs & - & - & - & + & + & + & + & + \\
\hline Arthrobranch & - & - & 1 & - & - & - & - & - \\
\hline Podobranch & - & - & - & - & - & - & - & - \\
\hline Epipods & + & + & - & - & - & - & - & - \\
\hline Exopods & + & + & + & - & - & - & - & - \\
\hline
\end{tabular}

setae on dorsal surface, dorsodistal margin not produced. Propodus 1.49 times longer than carpus, with numerous long simple setae on dorsal surface and shorter setae on ventral surface. Dactylus slightly compressed laterally, 0.65 times as long as propodus, terminating in slender, basally constricted unguis.

Fifth pereopod (Figure $3 H$ ) similar to fourth in general structure, but shorter and less setose, overreaching anterolateral margin of carapace by half length of dactylus. Dactylus 0.72 times as long as propodus.

Gill formula summarized in Table 1. Ventral apices of pleurobranchs directed posteriorly.

First pleopod (Figure $2 \mathrm{H}$ ) with endopod articulated at dorsodistal mesial angle of protopod, 0.45 times as long as exopod, somewhat sinuous and paddle-shaped, with long plumose setae on mesial margin. Endopods of second to fifth pleopods without appendix interna (Figure 2I), becoming shorter posteriorly (endopod of fifth pleopod rudimentary). Uropod (Figure $1 A$ ) with both rami not reaching posterior margin of telson; exopod distinctly shorter than endopod, truncate posteriorly, unarmed posterolaterally, lacking diaeresis; endopod tapering to rounded posterior margin.

COLOR IN LIFE (from color slides provided by P. K. L. Ng): Body and appendages generally white; carapace with black chromatophores along anterolateral and posterodorsal margins and on posterior part of branchial region. Abdomen with distinct band of black covering pleuron of third, entire fourth, and anterior part of fifth somites. Telson and uropods with black band at about midlength. 
Antennal basicerite with black chromatophores. Pereopods with few scattered black chromatophores. Protopods of first to fifth pleopods with tinge of dark brown.

Distribution: Known only from O'ahu, Hawai'i; at subtidal depth.

remarks: This new species can be distinguished from all known congeners, except $P$. sabsechota (Kemp, 1911) known with certainty only from the Andaman Islands (Kemp 1911, 1916), by the following characters: the antennal scaphocerite is unarmed on the lateral margin, except for the dorsolateral tooth; and the outer antennular flagellum is very short, composed of only six articles. Ledoyer (1970) reported P. sabsechota (as Pontophilus) from Madagascar, but his material appears rather similar to this new species than to the true $P$. sabsechota (see below). The following features indicate the affinity between the new species and P. sabsechota: the rostrum is broad, constricted at the middle, with a slightly concave anterior margin in the dorsal view; the carapace is armed with only one median spine (= gastric spine); the third abdominal somite has a distinct median carina. Nevertheless, comparison with the original and subsequent descriptions of $P$. sabsechota by Kemp $(1911,1916)$ revealed that there are many characters separating these two species. The rostrum is much narrower in $P$. breviflagella than in P. sabsechota: the width of the anterior margin is 0.16 of the carapace length in the new species, 0.47 in $P$. sabsechota. The dorsolateral carina on the carapace is divided into two sections in the two species, but the anterior end of the posterior section forms a blunt tooth in P. sabsechota, in contrast to not forming even a light angle in $P$. breviflagella. The hepatic carina is short and unarmed posterior to the hepatic spine in the new species, but the carina extends nearly to the posterior margin of the carapace and bears an additional tooth posterior to the hepatic spine in P. sabsechota. The posterodorsal margins of the second and fourth somites each have a distinct median notch in the new species, but they are devoid of a median notch in $P$. $s a b$ sechota. The fingers of the second pereopod are subequal in length to the palm and each bears an elongate unguis in $P$. breviflagella, but they are about twice the length of the palm and lack elongate unguis in $P$. sabsechota. The ischium of the second pereopod is slightly shorter than the merus in the new species, but it is unusually short in $P$. sabsechota. In the new species, the exopod of the uropod is shorter than the endopod and its distal margin is truncate, without a posterolateral tooth. In contrast, in P. sabsechota the exopod of the uropod is longer than the endopod and its posterior margin rounded, with an acute posterolateral tooth.

As already mentioned, specimens from Madagascar referred to $P$. sabsechota by Ledoyer (1970) appear very similar to this new species in the features of the carapace, telson, and uropod, according to the provided figures (Ledoyer 1970: pl. 21). Unfortunately, Ledoyer's specimens could not be located. Nevertheless, the following differences can be detected in comparison with the figures provided by Ledoyer (1970). The median spine on the carapace arises more anteriorly in $P$. breviflagella than in Ledoyer's specimens. The hepatic carina does not extend to the posterior half of the carapace in the new species, but it extends beyond the posterior 0.25 in the Madagascan specimens. The hepatic spine arises anterior to the level of the median tooth in P. breviflagella, but it arises from the same level as the median spine in Ledoyer's specimens. The antennal scaphocerite is much broader in the new species than in the Madagascan specimens; its lateral margin is slightly sinuous in $P$. breviflagella, rather than weakly convex as in the Madagascan specimens. If these features are true for the Madagascan specimens, they represent an undescribed species. It is strongly recommended that Ledoyer's material and additional specimens be examined to establish the taxonomic status of the Madagascan population.

Devaney and Bruce (1987) reported Pontophilus sp. aff. sabsechota from Enewetak Atoll, Marshall Islands, based on a single specimen (Madren Islet, lagoon side, 3.5-6 m, sand bottom, dredge, VII.1959, coll. F. C. Ziesenhenne). This female specimen is now deposited in the collection of the Los Angeles County Museum (LACM CR 19592971) and 
has been made available for examination. The affinity between the new species and $P$. sabsechota and proximity of the collecting locality initially led me to suspect that the specimen from Enewetak Atoll might represent the same species as $P$. breviflagella. However, it differs from the Hawaiian specimen in having a more robust body and sharply crested, distinctly notched lateral carinae on the carapace. I am confident that the specimen from Enewetak Atoll represents an undescribed species. That species will be described in a separate paper.

The distally truncate dorsolateral spines on the telson may be unusual among the species of the genus. A similar condition is so far known only for $P$. wilkinsae De Grave, 2000. In addition, Ledoyer (1970) illustrated distally truncate dorsolateral spines on the telson in the Madagascan specimen of $P$. sabsechota, but he did not provide any comment on those spines.

Although the eggs were not preserved in the specimen when examined, the color slide provided by $\mathrm{P}$. K. $\mathrm{L}$. $\mathrm{Ng}$ shows that the specimen carried four large eggs.

This new species represents the first occurrence of Philocheras in the central Pacific. As discussed by Chace (1984), Philocheras is well represented in the Indo-West Pacific, South Pacific, and eastern Atlantic, including the Mediterranean. On the other hand, it is poorly represented in the eastern Pacific (one species) and western Atlantic (two species), though the regions have been actively surveyed. Although shrimps of this genus may be easily overlooked in the field because of their small size and cryptic habitat, future study will probably reveal the existence of many unknown forms from the world's oceans.

ETYMOLOGY: Named from the Latin brevis (short) and flagella, in reference to the very short antennular flagella in this species. The name is considered a noun in apposition.

\section{ACKNOWLEDGMENTS}

I am grateful to P. K. L. Ng of the Raffles Museum of Biodiversity Research, National University of Singapore, for making this interesting specimen available for study.
Thanks are extended to S. De Grave of the Department of Zoology, University College Cork, National University of Ireland, for reviewing the manuscript, offering valuable comments, and providing me with some literature and to G. Davis of the Los Angeles County Museum for sending me the specimen of Philocheras sp. aff. sabsechota on loan.

\section{Literature Cited}

Bruce, A. J. 1994. Shrimps from Flat-top Bank, Timor Sea (Crustacea: Decapoda: Caridea). Raffles Bull. Zool. 42:743-756.

Burukovsky, R. N. 1990a. New and rare species of shrimps from the south-west part of the Indian Ocean. Zool. Zh. 70:36-41 (in Russian with English summary).

- 1990b. Shrimps from the Sala-yGomez and Nazca Ridges. Trudy Inst. Okeanol. Akad. Nauk SSSR 124:187-217 (in Russian with English summary).

Chace, F. A., Jr. 1984. The caridean shrimps (Crustacea: Decapoda) of the Albatross Philippine Expedition, 1907-1910, Part 2: Families Glyphocrangonidae and Crangonidae. Smithson. Contrib. Zool. 397:i-vi, $1-63$.

Christoffersen, M. L. 1988. Genealogy and phylogenetic classification of the world Crangonidae (Crustacea, Caridea), with a new species and new records for the south western Atlantic. Rev. Nordestina Biol. 6:43-59.

Crosnier, A. 1971. Sur quelques Crustacés Décapodes ouest-africains nouveaux ou rarement signalés. Bull. Mus. Natl. Hist. Nat., 3e sér., Zool. 9:569-595.

Dardeau, M. 1980. A new species of Pontophilus (Crustacea: Natantia: Crangonidae) from the Gulf of Mexico and the western Atlantic. Proc. Biol. Soc. Wash. 93:563572.

De Grave, S. 2000. A new Philocheras species (Decapoda, Crangonidae) from Hansa Bay, Papua New Guinea. Hydrobiologia 432: 49-56.

Devaney, D. M., and A. J. Bruce. 1987. Crustacea Decapoda (Peneaidea, Stenopodidea, Caridea, and Palinura) of Ene- 
wetak Atoll. Pages 221-233 in D. M. Devaney, E. S. Reese, B. L. Burch, and P. Helfrich, eds. The natural history of Enewetak Atoll. Vol. 2. U.S. Department of Energy, Office of Scientific and Technical Information, Oak Ridge, Tennessee.

Fujino, T., and S. Miyake. 1971. Descriptions of two new crangonid shrimps of the genus Pontophilus from Japanese waters (Crustacea, Decapoda, Crangonidae). Proc. Jpn. Soc. Syst. Zool. 7:26-38.

Holthuis, L. B. 1951. The caridean Crustacea of tropical West Africa. Atl. Rep. 2:7-187.

-1961. Report on a collection of Crustacea Decapoda and Stomatopoda from Turkey and Balkans. Zool. Verh. (Leiden) 47:1-67, pls. 1,2 .

Kemp, S. 1911. Notes on Decapoda in the Indian Museum. II: Descriptions of two new Crangonidae with observations on the mutual affinities of the genera Pontophilus and Philocheras. Rec. Indian Mus. (Calcutta) 6:5-12, pl. 2.

1916. Notes on Crustacea Decapoda in the Indian Museum. VI. Indian Crangonidae. Rec. Indian Mus. (Calcutta) 12:355-384, pl. 8.

Kim, J.-N., and K.-I. Hayashi. 2000. Two new shrimps of the genus Pbilocheras (Decapoda, Caridea, Crangonidae) from East Asian waters. J. Crustacean Biol. 20:687-698.

Leach, W. E. 1817. Malacostraca Podophthalma Britanniae; or descriptions of the British species of crabs, lobsters, prawns, and of other Malacostraca with pedunculated eyes, Part XV. Arding and Merrett, London [not seen].
Ledoyer, M. 1970. Étude systématique et remarques écologiques sur les Caridea recueillis principalement dans les biotopes de substrat meuble régions de Tuléar et de Nosy-Be. Ann. Univ. Madag. 7:121-157, pls. 1-25.

Man, J. G. de. 1920. The Decapoda of the Siboga Expedition. IV: Families Pasiphaeidae, Stylodactylidae, Hoplophoridae, Nematocarcinidae, Thalasocaridae, Pandalidae, Psalidopodidae, Gnathophyllidae, Processidae, Glyphocrangonidae, and Crangonidae. Siboga Exped. 39a3:1-318, pls. 1-25.

Stebbing, T. R. R. 1900. South African Crustacea, Part 1. Mar. Invest. S. Afr. 4:21-123, pls. 17-26.

Wicksten, M. K. 1989. Synalpheus arostris and Philocheras lapillus, two new species of caridean shrimp (Crustacea) from the tropical eastern Pacific. Proc. Biol. Soc. Wash 102:78-83.

Yaldwyn, J. C. 1960. Biological results of the Chatham Islands 1954 Expedition, 1. Crustacea Decapoda Natantia from the Chatham Rise; a deep water bottom fauna from New Zealand. N. Z. Dep. Sci. Ind. Res. Bull. 139:12-53 (plus index of 3 unnumbered pages).

- 1971. Preliminary descriptions of a new genus and twelve new species of natant decapod Crustacea from New Zealand. Rec. Dom. Mus. (Wellington) 7:85-94.

Zarenkov, N. A. 1968. Crustacea Decapoda collected by the Soviet Antarctic Expedition in the Antarctic and antiboreal regions. Issled. Fauny Morei SSSR 4:153199 (in Russian). 